\title{
DISCUSSION
}

\section{WHAT COLOUR IS YOUR OCEAN?}

\author{
Competing in overcrowded industries is no way to sustain high performance. The real opportunity is to \\ create blue oceans of uncontested market space. \\ (Kim and Mauborgne, 2005)
}

Red oceans represent all the industries that currently exist in the known market space where industry boundaries are defined and accepted and the rules of the game are to outperform rivals, achieve differentiation and competitive advantage - in order to survive. Inevitably, as the market becomes ever more crowded, opportunities for growth and increasing profits reduce and firms need to become more innovative. A Red Ocean Strategy is a business strategy based on competition.

Kim and Maubourgne $(2005)^{1}$ studied business launches in 150 companies in 30 industries and discovered a dramatic imbalance in favour of red oceans. Only $14 \%$ of these companies created new markets but in doing so they achieved significantly greater profits than the others. They argue that these companies created a blue ocean - an unknown market space where competition is irrelevant, where demand is created rather than fought over and growth is both rapid and profitable.

The logic behind the Blue Ocean Strategy is counterintuitive. Kim and Mauborgne (2005) make it clear that it's not about technology innovation - blue oceans seldom result from technological innovation. Often the underlying technology already exists with blue ocean creators linking it to what buyers value. And, there's no need to venture into distant waters to create blue oceans. Most blue oceans are created from within, not beyond, the red oceans of existing industries. Incumbents often create blue oceans within their core businesses. In the Blue Ocean Strategy, Value Innovation plays a dominant role in strategy formulation.

Although Kim and Mauborgne (2005) stress that technological innovation is not a defining feature in the creation of blue oceans nonetheless some form of innovation is required. After examining 24 innovation cases in order to develop a new framework to explain market domination,

1 Chan Kim, W., Maubourgne, R. (2005). Blue Ocean Strategy, Harvard Business School Press.
Buisson and Silberzahn $(2010)^{2}$ developed their four breakthroughs model to explain successful market domination. They concluded that innovation can lead to market domination and this innovation is achieved by four types of breakthrough - either separately or simultaneously: Techno-logical breakthrough, Business Model breakthrough, Design breakthrough, Process breakthrough. Swatch watches was a design breakthrough. The Dyson bagless vacuum cleaner was both a design and a technological breakthrough.

A common theoretical framework for comparing Red Ocean and Blue Ocean strategies is Hotelling's Beach Theory (1929) which posits that for as long as there are profits to be had in a particular market, more and more vendors will arrive to serve that market until it reaches the saturation point and everyone more or less breaks even. In their analysis of the Dutch retail industry Burke, van Stel and Thurik (2009) ${ }^{3}$ used Beach Theory as their framework "because looking at entire industries in this way allows you to tell over time whether an innovation strategy or a competitive strategy is best." Examining profits and numbers of vendors for 41 shop types over a 19-year period (1982-2000), they found that the Blue Ocean Strategy and competitive strategies overlap and that managers do not face a discrete either/or decision between each strategy. Their evidence indicated that Blue Ocean Strategy had prevailed as a dominant long-term viable strategy.

2 Buisson, B., Silberzahn, P. (2010). Blue Ocean or Fast-Second Innovation? A four breakthrough model to explain successful market domination, International Journal of Innovation Management, 14(3): 359-378.

3 Burke, A., Van Stel, A., Thurik, R. (2009). Blue Ocean versus Competitive Strategy: Theory and Evidence. ERIM Research Report Series Research in Management. 
Nithisathian, Kittichok and Walsh ${ }^{4}$ posited that just as Blue Ocean Strategy states that a Red Ocean Strategy (Competitive Strategy) does not guarantee success for the firm, a Purple Ocean Strategy claims that Blue Ocean Strategy cannot guarantee business success in the long-term since the blue ocean will ultimately turn red. The Purple Ocean Strategy believes that in today's business world firms require both innovative ideas as well as a series of strategies to compete with rivalry and remain functional in the long-term. Cavagnetto and Gahir $(2013)^{5}$ also argue that there are no permanent Blue Oceans - ultimately the ocean will become purple. Following Barwise and Meehan (2012) ${ }^{6}$ they consider the examples of Motorola, Nokia and Samsung and argue that firms wishing to avoid suffering the same fate as Nokia should set as their goal the creation of "purple areas of ocean beyond the edge of actual markets with a constant organic evolution and a reliable communication towards customers regarding their core promise." 7

Whilst a blue ocean free from competition sounds idyllic, inevitably other players will appear. They will seek to innovate past their competitors or imitate them or capture a niche in the new market. Indeed they may even create a new blue ocean. So is being a Pioneer and creating a blue ocean a sound strategic move? Is it ultimately better to be a Fast Follower? Markides and Geroski $(2005)^{8}$ contend that it is. Patrick Barwise (2012) ${ }^{9}$ asserts that “.... the brutal truth is that most pioneers end up flat on their faces with arrows in their backs, forgotten. Either the new market turns out to be a mirage, or the pioneer is soon overtaken by an early follower who executes better." Usually the Pioneer takes the risks, makes mistakes. The Fast Follower learns from these and from the initial market response to the pioneer's offer. He modifies the offering, invests wisely and often goes on to colonise the market.

4 Nithisathian, K., Walsh, J. (2013). Purple Ocean Strategy Concept Paper: Content Analysis from Interviews and Literature Review. Paper presented at the SIU International Conference (January 30-31, 2013).

5 Cavagnetto, S., Gahir, B. (2013). Shades of Purple Strategy. CRIS Bulletin, 2013/01.

6 Barwise, P., Meehan, S. (2012). Innovation Beyond Blue Oceans. Market Leader, 4: 24-27.

7 Ibid p. 90.

8 Markides, C., Geroski, P. (2005). Fast Second - How Smart Companies Bypass radical Innovation to Enter and Dominate New Market. San Francisco, Jossey-Bass.

9 The Myth Of 'Pioneer Advantage - Patrick Barwise, Emeritus Professor - London Business School - February 02, 2012 (http://www.cmo.com/content/cmo-com/home/articles/2012/2/2/the-myth-of-pioneer-advantage.html - consulted 2 Feb. 2014)
When referring to Blue Ocean Strategy ${ }^{10}$ Gandellini and Venanz (2011) 11 concede that the "major contribution of the book is that of having explicitly attempted a comprehensive systematization of the strategic process that allows the identification and exploitation of new industry sectors and market spaces, in which, at least initially, a competitive system does not exist by definition. Or, alternatively [...] the identification of new moves that displace the competitors at least for some time [...] however they refer to the Blue Ocean Strategy as "apparently the new "must", or at least an objective to pursue. It certainly was a "technically" excellent marketing endeavor, based on the expedient of an original title, an intriguing subtitle, new labels for several old concepts and similar views expressed by other authors [...], an intelligent and well targeted communication campaign, and the prestige of the sponsoring business schools (Harvard and INSEAD). However, any reader of the book cannot avoid realizing that the statement "... make the competition irrelevant" $i s$, in the best case, a little bold, even in specific market contexts mentioned by the authors in support of their thesis, and even more so in periods of economic crisis."

Red oceans and blue oceans have always co-existed. Inevitably purple oceans form where they overlap. Does the Blue Ocean Strategy have value? Is it overrated? Is a new paradigm needed? Is an ocean typology of value? Does it exclude the various nuances of how markets work, how firms compete, how firms innovate? Does the corporate business strategist even think about the colour of the ocean or is he more concerned with surviving, with keeping up with or overtaking the competition? To what extent do firms need to innovate to survive and in what way? Should a firm seek to dominate existing markets or look for opportunities to create new ones? If a firm moves into a new market should they be a Pioneer or a Fast Follower?

Author

Gillian Pritchett, MA. CPFA.

Teacher of various MBA programmes including International Business Strategy on the CEMS-MIM programme at the University of Economics, Prague

Founder of The Business Launchpad

Consultant

pritchett.g@gmail.com

10 Chan Kim, W., Maubourgne, R. (2005). Blue Ocean Strategy, Harvard Business School Press.

11 Gandellinia, G., Venanz, D. (2011). Purple Ocean Strategy: How To Support SMEs' Recovery. Procedia - Social and Behavioral Sciences, 24: 1-15. 